\title{
ESCRITÓRIO TÉCNICO RAMOS DE AZEVEDO, SEVERO \& VILLARES: LONGEVIDADE, PLURALIDADE E MODERNIDADE (1886-1980)
}

BEATRIZ PICCOLOTTO SIQUEIRA BUENO

Universidade de São Paulo, São Paulo, São Paulo, Brasil

DOI: http://dx.doi.org.br/10.11606/issn.1980-4466.v0i19p194-214

\section{RESUMO}

Este artigo versa sobre a exposição Escritório Ramos de Azevedo: a arquitetura e a cidade e busca revelar o Escritório, Ramos de Azevedo e seus parceiros, por meio de alguns projetos feitos para o Estado e para particulares. De rara beleza, os desenhos encerram diversas narrativas, põem luz em comitentes, sócios e auxiliares, dando pistas sobre a cadeia produtiva que envolvia as obras e garantia a credibilidade do protagonista no imaginário coletivo. A bico de pena, aquarela ou blueprint, seus carimbos estampam abreviaturas, permitindo-nos vislumbrar arquitetos, engenheiros e desenhistas de um escritório que no auge chegou a integrar 500 colaboradores. Os projetos, que em seus pormenores chegam à escala do mobiliário e da descrição dos materiais, dão pistas sobre o cotidiano do Escritório, mas também nos convidam a caminhar pela cidade imaginando-a em construção. Aliás, é disso que também se trata: de uma São Paulo em franco processo de modernização, espalhando-se, verticalizando-se e arranhando os céus. Destacamos as três fases do Escritório: de 1886 à morte de Ramos; de 1928 a 1965, quando segue protagonizado por Ricardo Severo e Arnaldo Villares; e de 1965 a 1980, protagonizado por Roberto Pereira de Almeida e Affonso Iervolino. Especializadas, as obras públicas entremeiam-se às feitas para particulares e ambas merecem preservação tanto quanto os desenhos que as representam.

\section{PALAVRAS-CHAVE}

Escritório Ramos de Azevedo, Severo \& Villares. Arquitetura. São Paulo. 


\section{ESCRITÓRIO TÉCNICO RAMOS DE AZEVEDO, SEVERO \& VILLARES: LONGEVITY, PLURALITY AND MODERNITY (1886-1980)}

BEATRIZ PICCOLOTTO SIQUEIRA BUENO

Universidade de São Paulo, São Paulo, São Paulo, Brasil

DOI: http://dx.doi.org.br/10.11606/issn.1980-4466.v0i19p194-214

\section{ABSTRACT}

This article discusses the Ramos de Azevedo Office: Architecture and City exhibition that presents the office run by Ramos de Azevedo and his partners through some of their designs for the state government and private clients. These designs display rare beauty and contain several narratives, shed light on principals, partners and auxiliaries, and disclose a portion of the supply chain of those works that assured the credibility of their protagonist in the collective mind. Whether in ink, watercolor or blueprint, and with stamps bearing their initials, they offer us a glimpse of the architects, engineers and draftsmen in an office that, at peak activity, employed 500 people. Projects drilled down up to furnishings and the description of materials tell us more about the everyday practice at the office, and invite us to walk around the city and imagine it as a work in progress. And indeed it was: the sprawling, verticalizing and skyscraping city of São Paulo was being modernized at full tilt. One can split the office's history into 3 periods: from 1886 to Ramos' death; from 1928 to 1965, when Ricardo Severo and Arnaldo Villares took over; and from 1965 to 1980, when Roberto Pereira de Almeida and Affonso Iervolino took over. Public works alternated with buildings for private clients, all deserving preservation, as well as the designs that represent them.

\section{KEYWORDS}

Ramos de Azevedo, Severo \& Villares Office. Architecture. São Paulo. 


\section{INTRODUÇÃO}

Falar do Escritório Técnico Ramos de Azevedo, Severo \& Villares é falar da história de São Paulo, pois ambas as trajetórias se fundem e confundem. Este foi sem dúvida o maior e o mais moderno escritório atuante na cidade por quase um século.

A exposição Escritório Ramos de Azevedo: a arquitetura e a cidade é oportuna para rememorar seu legado, cujos meandros ainda carecem de esclarecimentos. Enseja mais perguntas que respostas, especulando sobre a ponta de um iceberg cuja base é infinitamente maior e merecedora de pesquisa.

Em 80 painéis há reproduções de cerca de 100 desenhos pertencentes ao Arquivo Histórico de São Paulo e à Faculdade de Arquitetura e Urbanismo da Universidade de São Paulo (FAU-USP), entremeados a fotografias e pequenas relíquias gentilmente disponibilizadas pelos herdeiros ${ }^{2}$

\footnotetext{
1. Exibida no Centro Cultural Correios de São Paulo, de 17 de janeiro a 17 de março de 2015, para comemorar o aniversário de 461 anos da cidade. Permaneceu de 9 de abril a 17 de maio de 2015 no Centro de Preservação Cultural da Universidade de São Paulo (CPC-USP), sendo exibida em seguida na Escola Politécnica (Poli-USP) e na Faculdade de Arquitetura e Urbanismo (FAU-USP). 2. Agradecemos especialmente a Paulo Villares de Oliveira - bisneto de Ramos de Azevedo e neto de Arnaldo Dumont Villares -, Mirza Pellicciotta - neta de Domingos Pellicciotta - e Luna Lopez Brandão -bisneta de Manoel Gomes da Silva - pelas entrevistas e documentos cedidos para a exposição.
} 
de Arnaldo Dumont Villares, Domingos Pellicciotta e Manoel Gomes da Silva. De rara beleza, os desenhos seduzem pela qualidade artística e entretecem nas suas entrelinhas diversas narrativas que inspiraram a linha curatorial da mostra.

As cópias expostas em suas dimensões reais revelam a longevidade, pluralidade e modernidade do Escritório, tripé eleito para suscitar debate, em meio à cidade que ajudou a construir num curto período de tempo.

\section{LONGEVIDADE}

O mais longevo escritório de arquitetura, engenharia e construção de São Paulo contou cerca de 94 anos de existência desde a chegada de Ramos de Azevedo à capital em 1886 até seu possível fechamento em 1980³. Impressiona sua capacidade de produção, assinando em torno de 4.000 projetos na capital e fora dela, a maioria nossas principais referências em termos de Patrimônio Cultural hoje: Secretaria da Fazenda (1886-1891), Secretaria da Agricultura (1892-1896), antiga sede da Bolsa de Mercadorias (1933-1937), Quartel da Luz (1888-1892), Escola Politécnica (Edifício Ramos de Azevedo, 1912-1920), sede dos Laboratórios da Escola Politécnica (Edifício Paula Souza, 1895-1896), Liceu de Artes e Ofícios (atual Pinacoteca do Estado, 1897-1900), Escola Normal (Caetano de Campos, 1892-1894), Theatro Municipal (19031911), Edifício dos Correios e Telégrafos (1920-1922), Palácio das Indústrias (1911-1924), Mercado Municipal (1922-1933), Palácio da Justiça (1920-1933), Faculdade de Direito (1933), dentre outras. Além dos diversos edifícios projetados para particulares, como a Casa Lutetia (Praça do Patriarca, n. 78), a Casa Palmares (Rua Boa Vista, n. 127), o Edifício José K. Fakhoury (Rua 15 de Novembro, n. 251), o Edifício Malvina Chammas Curi (Rua Álvares Penteado, n. 195); sedes de bancos, como o Banco Português do Brasil (Rua 15 de Novembro, n. 194), o Banco Comercial de São Paulo (Rua 15 de Novembro, n. 324/336); hotéis, como o Hotel Central e o Hotel Britânia na Avenida São João; incontáveis palacetes, como a Casa das Rosas, na

\footnotetext{
3. Acreditamos ser 1980 o ano de encerramento das atividades do Escritório em razão da carta, assinada pelo engenheiro Paulo Bonilha e encaminhada ao Arquivo Histórico de São Paulo, doando os 1683 desenhos arquitetônicos que hoje integram o Fundo Particular Escritório Técnico Ramos de Azevedo, Severo e Villares pertencente à instituição. Ver: <www.projetosirca.com.br>. Acesso em: 31 maio 2015.
} 
Avenida Paulista, dentre muitos outros exemplares ainda sobreviventes. Da segunda fase, destacam-se o Conjunto Poliesportivo do Pacaembu (1939), a nova sede do Jockey Club na Cidade Jardim, o Edifício Liberty Paulista (Rua Libero Badaró, n. 164/170), o Edifício Britânia (Rua Libero Badaró, n. 152), o Edifício Santa Cruz (Rua José Bonifácio, n. 89/93), o Ouro para o Bem de São Paulo (Rua Álvares Penteado, n. 23), o Edifício José Paulino Nogueira (Largo do Paissandu, n. 72) etc.

O Escritório chegou a ter filiais em Santos e no Rio de Janeiro e durante 42 anos foi liderado por Ramos de Azevedo (1886-1928), 12 anos por Ricardo Severo (1928-1940), 25 anos por Arnaldo Dumont Villares (1940-1965) e os últimos 15 anos pelos politécnicos Dr. Roberto Pereira de Almeida e Affonso Iervolino.

No amplo leque temporal de existência, alinhou-se ao que havia de mais moderno em termos de arquitetura, destacando-se pela adesão ao ecletismo na sua primeira fase e ao art déco na etapa sob a liderança de Arnaldo Dumont Villares.

Creditamos a sua longevidade mais à excelência, seriedade e respeitabilidade angariadas com muito trabalho e menos às redes de sociabilidade de seus protagonistas.

Em todas as etapas ocupou-se do desenho à execução das obras, acumulando por vezes a construção de projetos de terceiros, como no caso do prédio da Light e do Edifício Matarazzo.

\section{PLURALIDADE}

Tantas obras em simultâneo não poderiam ser creditadas apenas aos líderes do Escritório, e disso decorre o segundo aspecto eleito para exploração como linha curatorial da mostra - a pluralidade.

Surpreende o fato de apenas quatro anos depois de ter chegado a São Paulo Ramos de Azevedo já contar com 500 colaboradores. Por ocasião de seu aniversário, recebeu-os em procissão em sua casa na Rua Pirapitingui para um lauto banquete ${ }^{4}$.

Atribuímos a Ramos de Azevedo alta capacidade empresarial e de gestão, sendo ele certamente o mentor de uma engrenagem que se manteve

4. Correio Paulistano, 10/12/189o. Fundação Biblioteca Nacional, Rio de Janeiro. 
ativa com os mesmos procedimentos por longos anos. Com seu carisma e sensibilidade ímpares, soube arregimentar o que havia de melhor, encabeçando desde o início uma equipe de talentosos profissionais. Com uma capacidade de trabalho invejável, envolveu-se com as mais diversas frentes de investimentos (bancos, fazendas para extração de cal, mármores e madeiras, lojas de importação de materiais, loteamentos), além de dirigir e ensinar na Escola Politécnica e no Liceu de Artes e Ofícios. Em paralelo, com seus dotes gerenciais, imprimiu ritmo aos trabalhos no Escritório, congregando a equipe com práticas de motivação empresarial e garantindo o envolvimento de todos no cumprimento das obras. Os aniversários do Dr. Ramos - como era respeitosamente chamado pelos funcionários - nunca passaram em branco, assim como as diversas datas comemorativas do Escritório, aniversário dos funcionários e, sobretudo, a conclusão das obras, cujos banquetes ou simples churrascadas estão eternizadas nas fotos que foram exibidas nas vitrinas da mostra.

Se no início o Escritório envolveu profissionais formados na Europa - Ramos na Escola Especial de Engenharia Civil da Universidade de Gante e na Academia Real de Belas-Artes, ambas na Bélgica, Ricardo Severo na Academia Politécnica do Porto, Arnaldo Villares na Crystal Palace Engineering School ${ }^{5}$ em Londres -, aos poucos notabilizou-se por agrupar um séquito de ex-alunos da Escola Politécnica e do Liceu de Artes e Ofícios, instituições que Ramos de Azevedo ajudou a criar e a dirigir.

A arquitetura eclética envolvia novos procedimentos e mão de obra especializada e, nesse aspecto, a vinculação dos protagonistas com a Poli e o Liceu foi essencial para a formação de quadros técnicos capazes de dar cabo à nova estética. Pelo Escritório passaram os melhores profissionais, polarizando inclusive artesãos imigrantes recém-chegados e relacionados aos mais diversos ofícios.

\footnotetext{
5. Cf. Diploma da Crystal Palace Engineering School, emitido em 1908, e currículo elaborado por Arnaldo Dumont Villares, em 1925, endereçado à Secretaria da Agricultura, Comércio e Obras Públicas do Estado de São Paulo, solicitando autorização para continuar exercendo a profissão de engenheiro, arquiteto e construtor, visto que o curso realizado na Inglaterra não era oficialmente reconhecido em nosso meio. Coleção dos Herdeiros de Arnaldo Dumont Villares.
} 
FIGURA 1

Ramos de Azevedo e equipe entre $1924 \mathrm{e}$ 1928. Ao centro vemos o protagonista ladeado pelos sócios Arnaldo Dumont Villares, à esquerda, e Ricardo Severo, à direita. Em frente ao chefe, sentados na primeira fileira, da esquerda para direita, os jovens desenhistas Domingos

Pellicciotta e Pedro

Giannini. Coleção da Família de Domingos Pellicciotta.

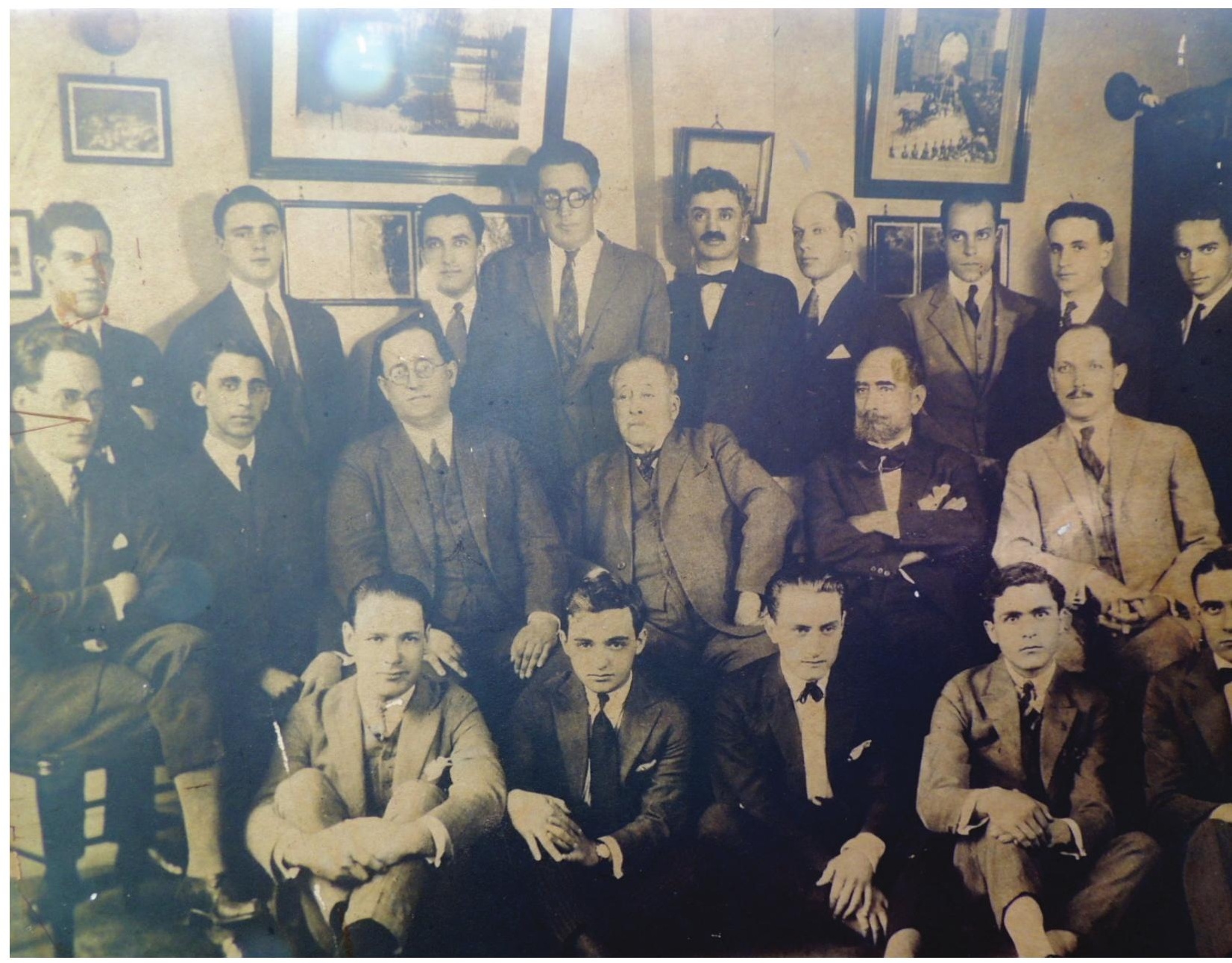

O Escritório atuou em pelo menos duas sedes: no edifício Casa Ramos de Azevedo, sito à Rua Boa Vista, n. 136 (2ํㅡ e 6o andares),e no Edifício Britânia, sito à Rua Libero Badaró, n. 152 ( $12^{\circ}$ e $13^{\circ}$ andares). No $13^{\circ}$ ficavam os projetistas/calculistas e no $12^{\circ}$ a Seção de Obras, reunindo cerca de 50 profissionais de gabinete, sem contar os empreiteiros, mestres de obras e operários alocados nos canteiros. Concertadamente, todos atuavam sob a supervisão cuidadosa de chefias especializadas por área, organizadas em turmas, que trocavam cotidianamente experiências nos finais de tarde ou mesmo de manhã nos cafés envoltórios ao Escritório, afinando os projetos e equacionando as obras em curso. 
FIGURA 2

Sede do Escritório no Edifício Britânia.

Em pé, o único

sem gravata, vê-se

Domingos Pellic-

ciotta. Coleção dos

Herdeiros de Arnaldo

Dumont Villares.

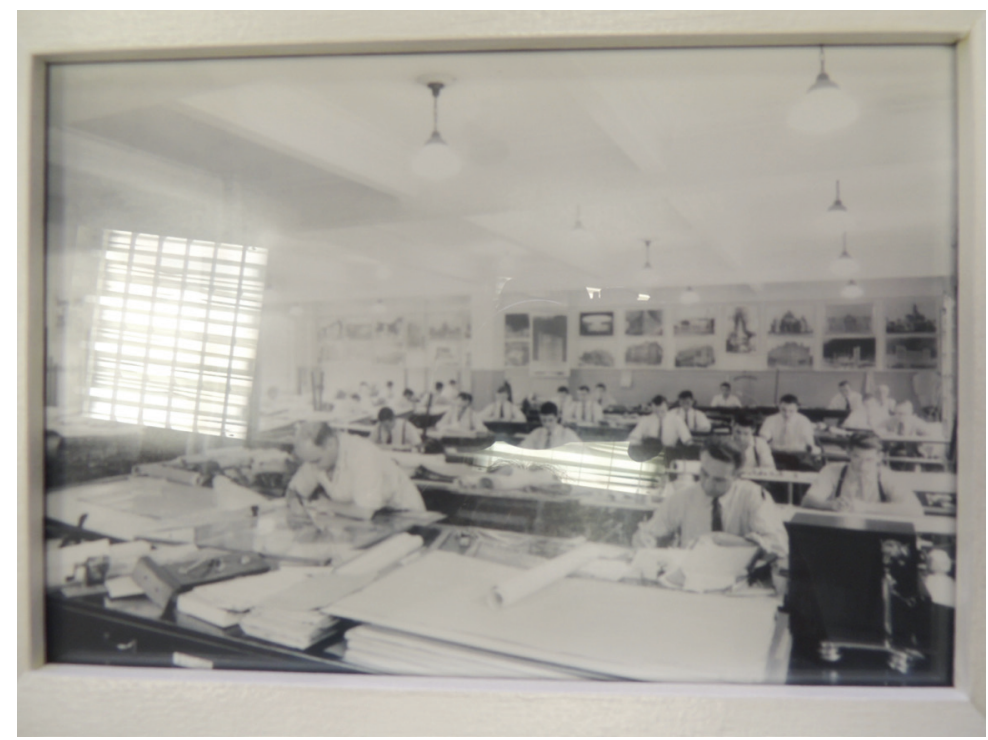

FIGURA 3

Desenho elaborado por Domingos Pellic-

ciotta dando uma ideia da vista que se tinha das janelas do

$13^{\circ}$ andar do Edifício Britânia, sede do Escritório a partir dos anos 1943, quando o prédio foi inaugu-

rado. Coleção da Família de Domingos Pellicciotta.

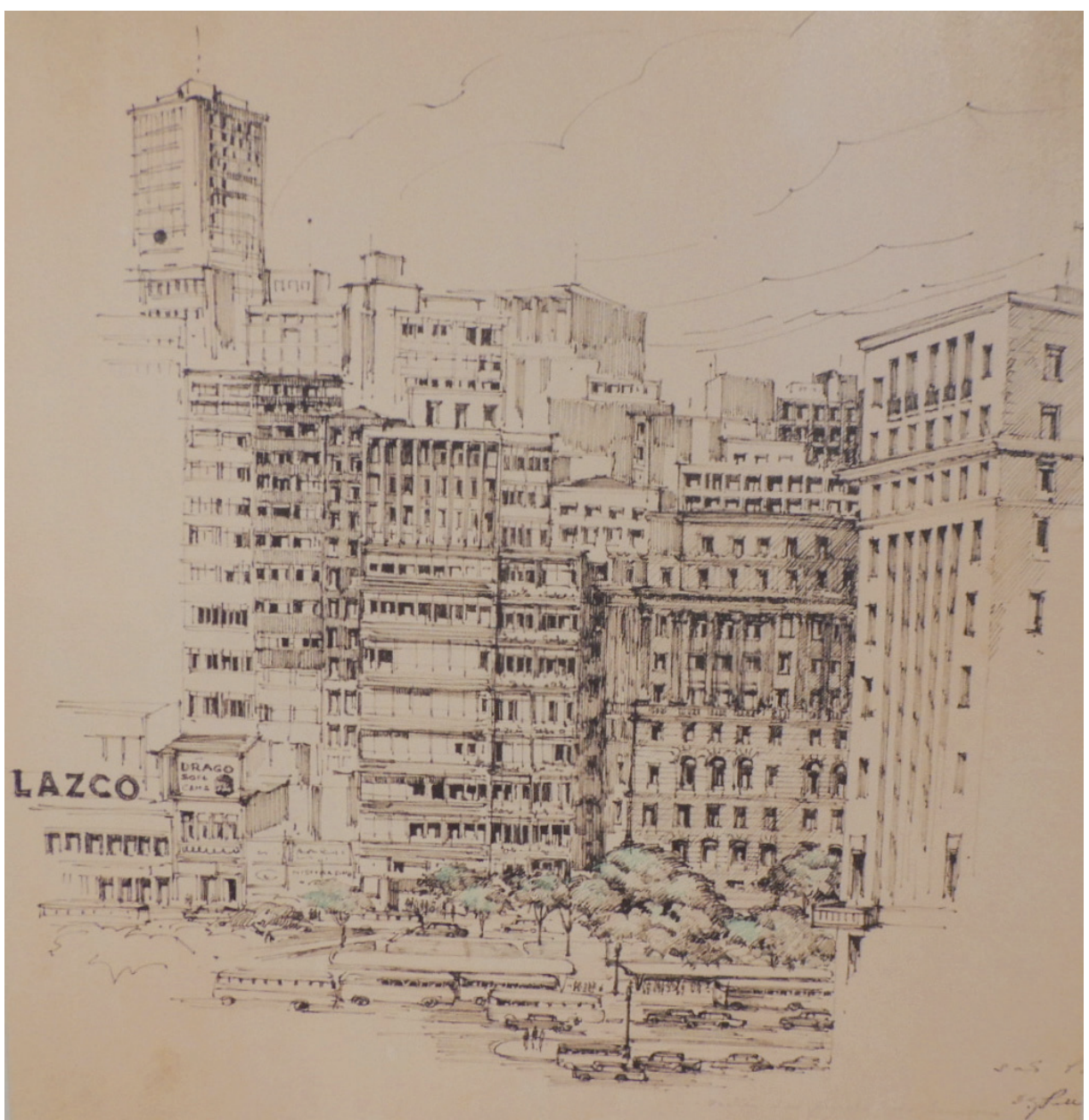


Segundo nos contou o Prof. Dr. Nicola Paciléo Netto da Escola Politécnica, ex-aluno e membro do Escritório entre 1959 e 1968, ao final das tardes, os integrantes do $12^{\circ}$ andar subiam ao $13^{\circ}$ para discutir o trabalho do dia e programar a jornada seguinte, sob a atenta supervisão do Dr. Roberto Baptista Pereira de Almeida e de Affonso Iervolino, então diretores do Escritório.

Esses procedimentos garantiam ritmo às obras, cumprimento dos prazos, honrando compromissos e assegurando a excelência que lhes conferia credibilidade no imaginário coletivo. Assim Ramos de Azevedo, Severo \& Villares não se tornou uma marca por acaso.

A historiografia eternizou Ramos de Azevedo e, mais recentemente Ricardo Severo, mas sozinhos não teriam dado conta de tantas obras em simultâneo se não fosse a equipe que souberam compor de forma tão afinada. As fotos inéditas exibidas nas vitrinas da exposição revelam as outras faces dos hoje anônimos que compunham o grupo, ainda carentes de investigação.

Nessa direção, buscou-se pôr luz nos rostos menos conhecidos dos integrantes da equipe, ambicionando no futuro cruzá-los com as múltiplas assinaturas que ornamentam os convites e cartões comemorativos do Escritório.

FIGURA 4 e 5

Equipe fotografada no Almoço Comemorativo dos 50 Anos do Escritório Técnico Ramos de Azevedo Severo \& Villares (1886-1936) ocorrido em 1936 no Hotel Esplanada, em pleno Vale do Anhangabaú, diante

da maior joia do Escritório, o Teatro Municipal. Coleção dos Herdeiros de Arnaldo Dumont Villares.

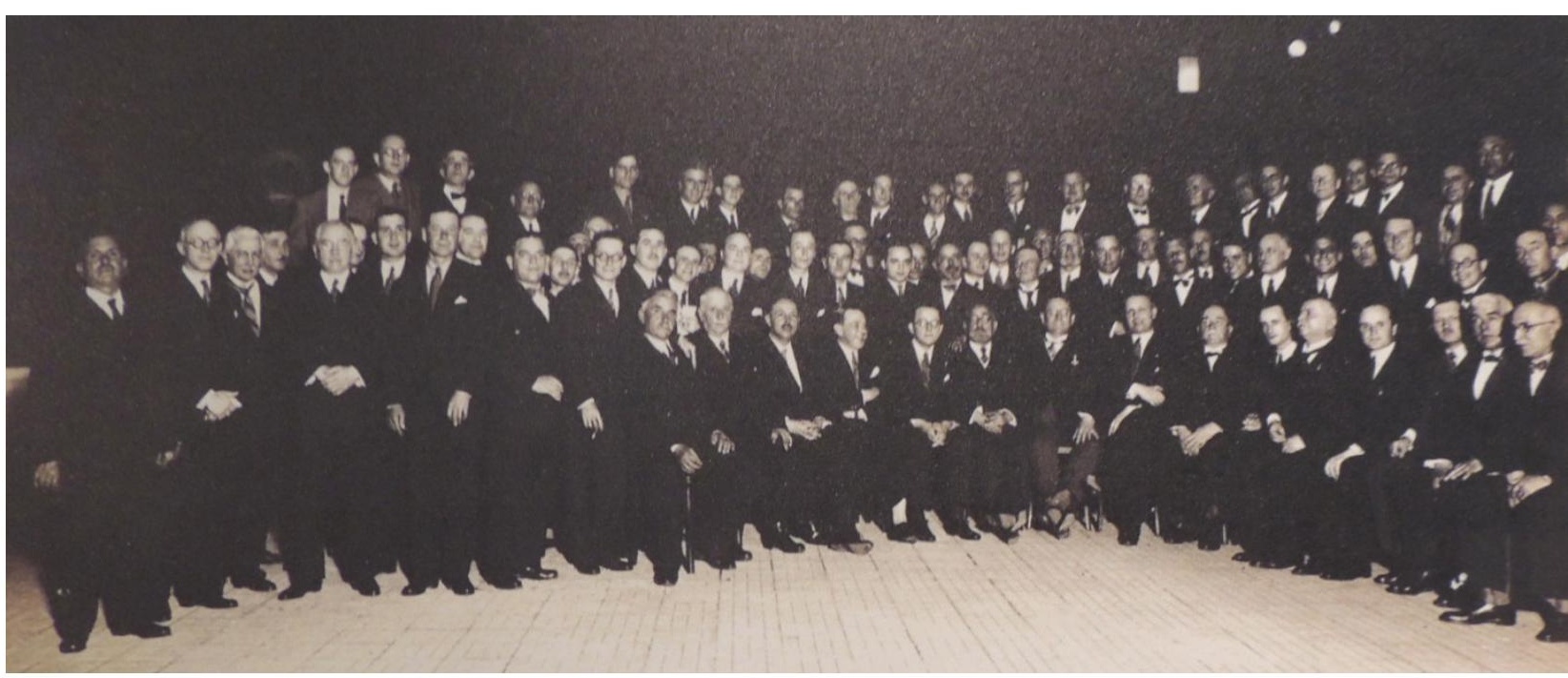




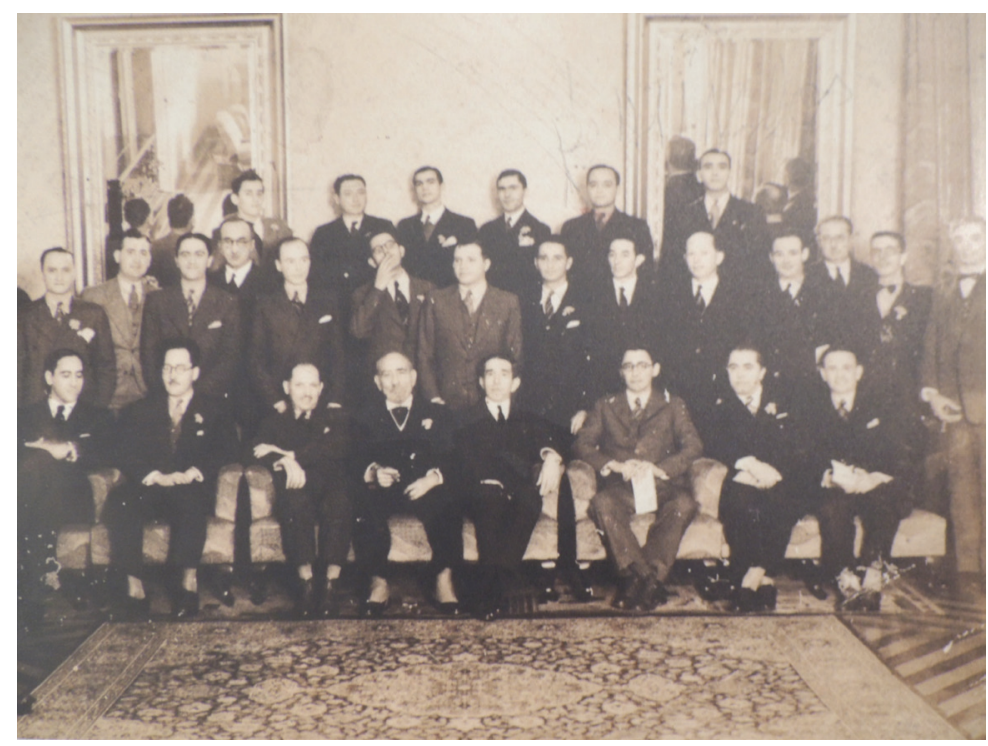

FIGURA 6

O convite do Almoço

Comemorativo dos

50 Anos do Escritório Técnico Ramos de Azevedo Severo \&

Villares (1886-1936)

revela as assinaturas

dos integrantes em 1936. Sobressa o humor nos dizeres do cardápio associando-se menu às etapas do processo construtivo. Coleção dos Herdeiros de Arnaldo Dumont Villares.

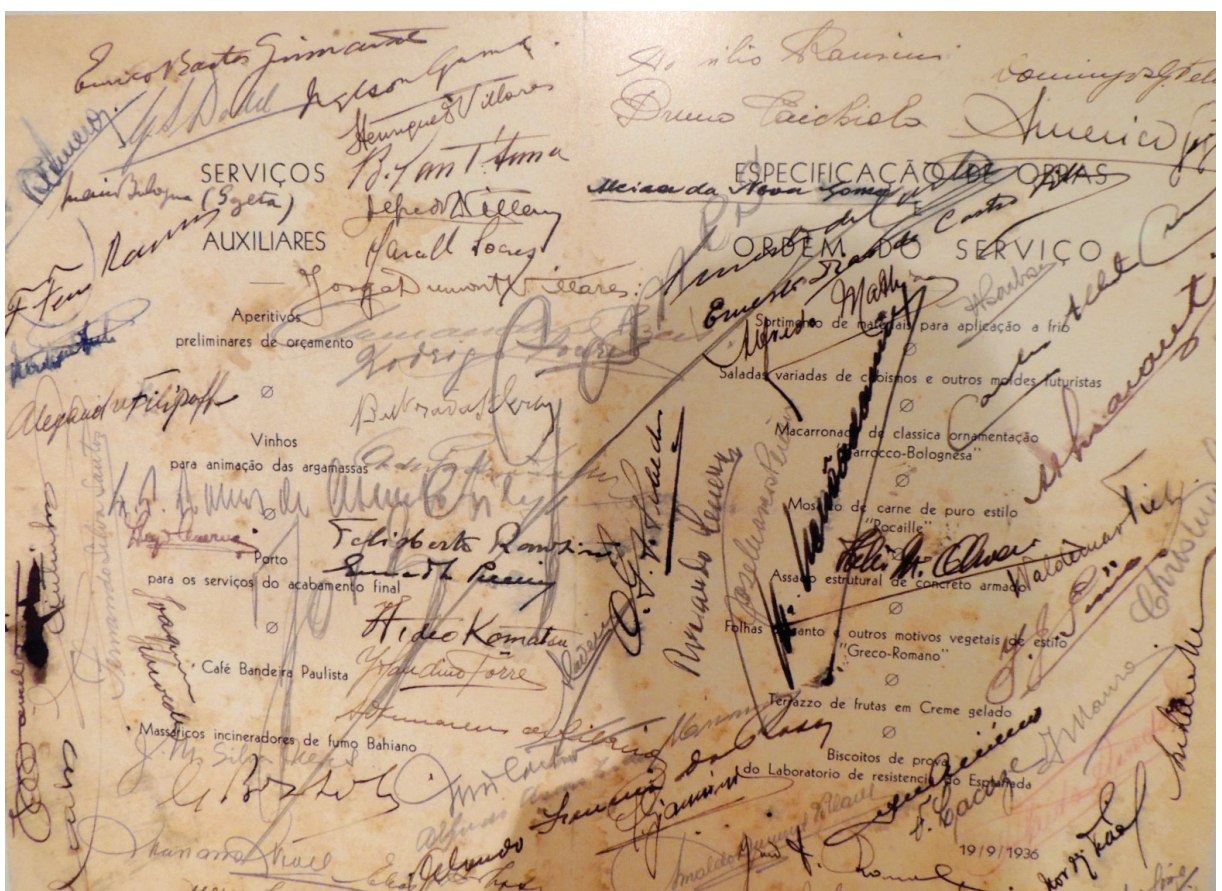

Para tanto, preciosas foram as coleções dos herdeiros de Arnaldo Dumont Villares, de Domingos Pellicciotta (desenhista formado no Liceu de Artes e Ofícios) e de Manoel Gomes da Silva (estucador, trolha, frentista, mestre de fachadas português). 
FIGURA 7

frentista Manoel Gomes da Silva, o terceiro à direita,

diante da obra do

Palácio das Indús-

trias que ajudou construir. Coleção da Família de Manoel Gomes da Silva.

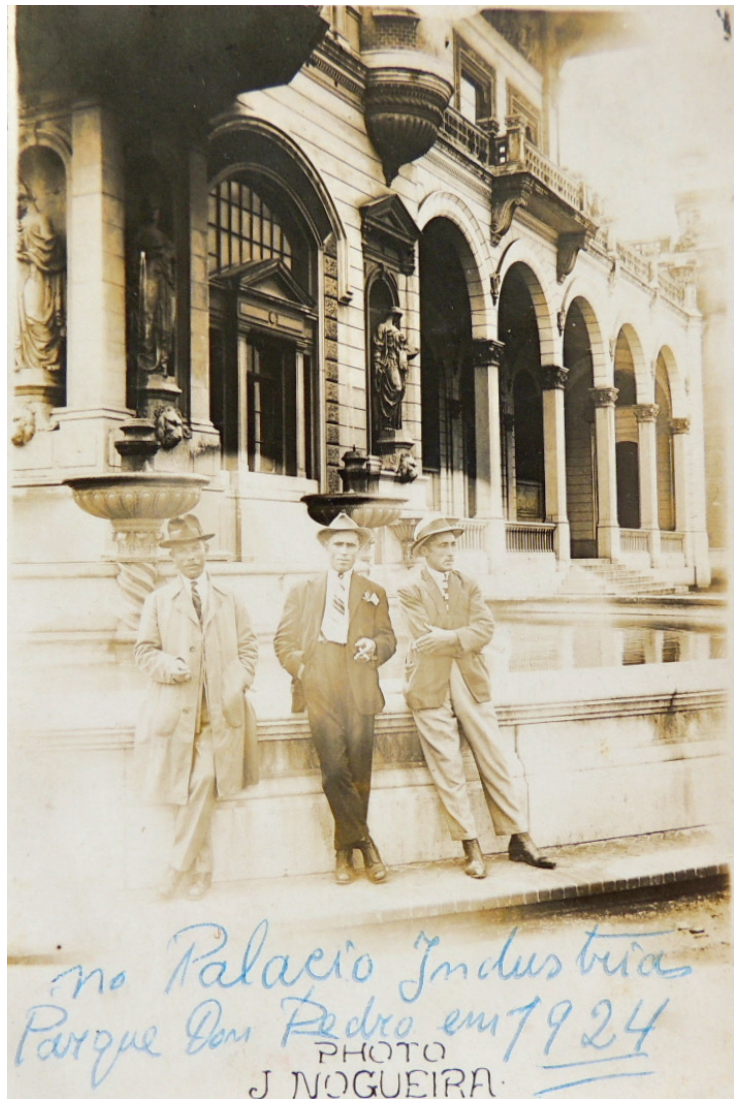

FIGURA 8

Operários envolvidos na obra do Mercado

Municipal em foto comemorativa da sua conclusão. Coleção da Família de Manoel Gomes da Silva.

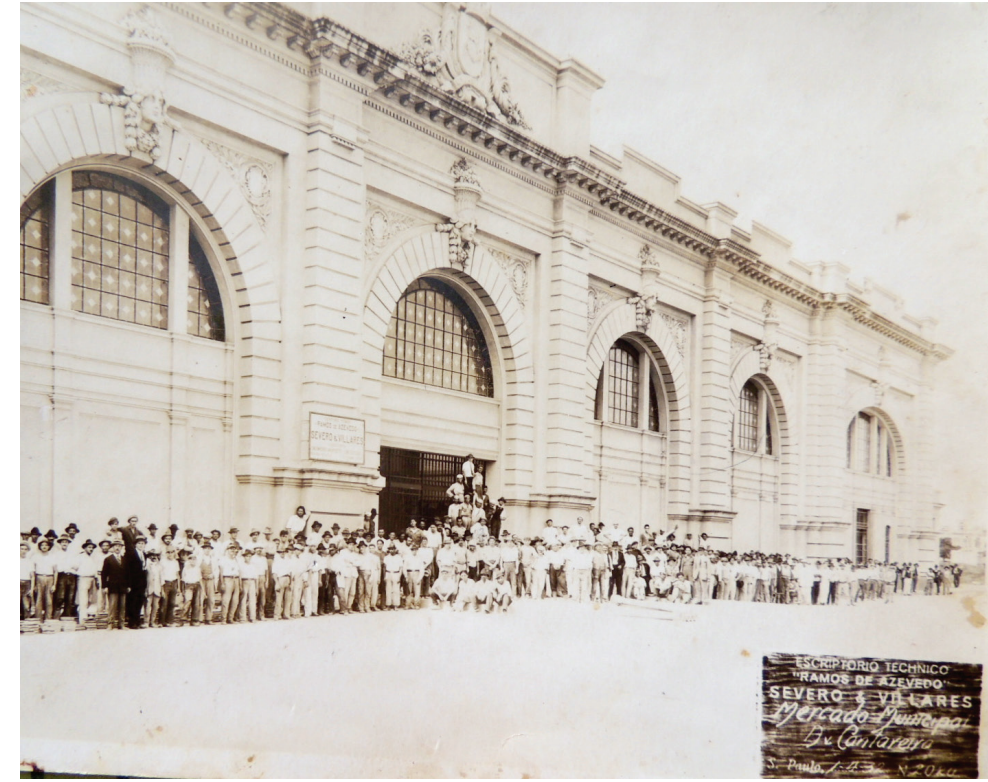

Revista CPC, São Paulo, n.19, p.194-214, jun. 2015. 
Nesses poucos meses em que a mostra esteve em cartaz no Centro Cultural Correios-SP e no Centro de Preservação Cultural da Universidade de São Paulo (CPC-USP), surgiram diversos familiares de antigos integrantes do Escritório, como o neto de Américo Giglio, o neto de Pedro Giannini, além dos poucos ainda vivos, como o professor Nicola Paciléo Netto.

FIGURA 9

Domingos Pellicciotta cursava Desenho

Architectônico no

Liceu de Artes

Ofícios quando

Ramos colocou-lhe um cartão aos ombros,

chamando-o para

trabalhar, seduzido

pela qualidade do

seu desenho. Era

artista, escultor e hábil

desenhista. Ao que

tudo indica, tal prática

de arregimentação foi

recorrente. Pellicciotta

ingressou no Escritório

em 1924, aos 17 anos,

diplomando-se em

1926. Ali permaneceu

até falecer em 1970

Coleção da Família de

Domingos Pellicciotta.

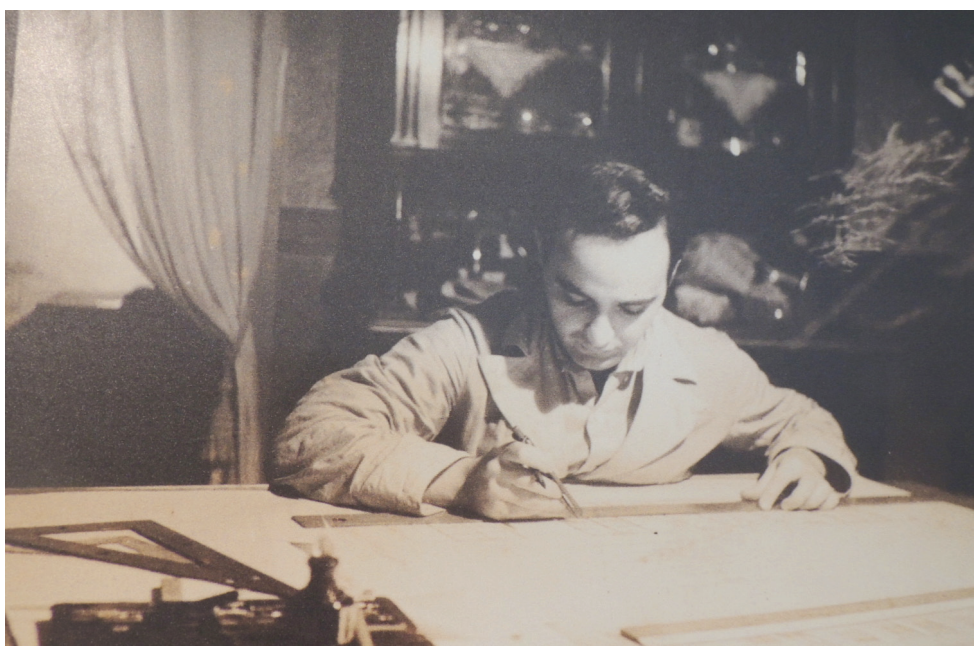

FIGURA 10

Algumas faces dos tantos integrantes do Escritório. Coleção da Família de Domingos Pellicciotta.

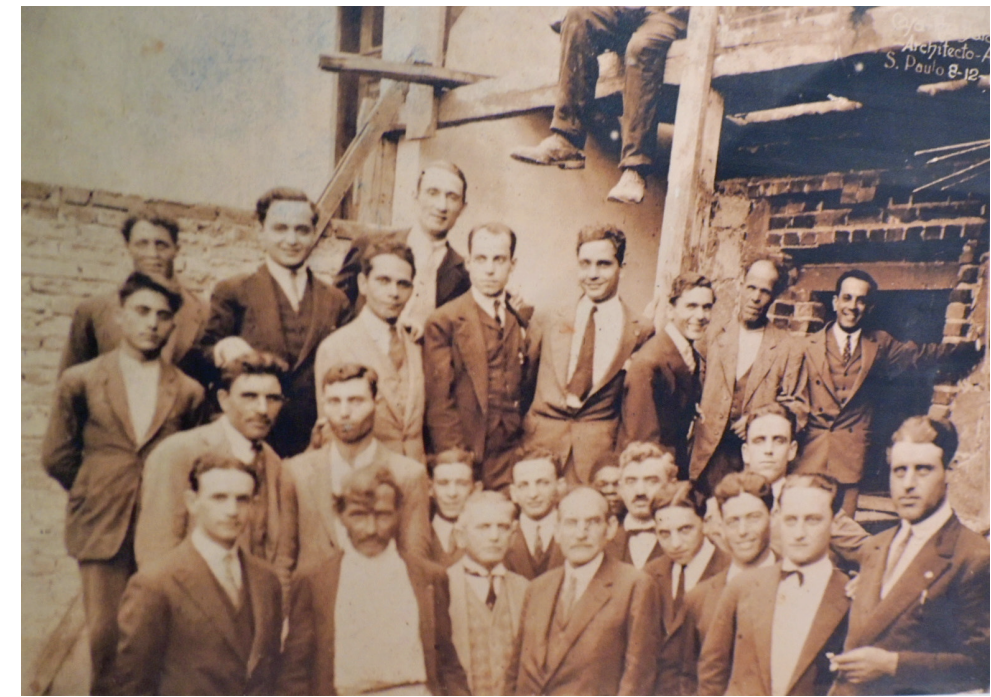




\section{MODERNIDADE}

À coesão e ao comprometimento da equipe creditamos o sucesso e a qualidade das obras, o que nos remete à questão da modernidade do Escritório. Foi, sem dúvida, o primeiro escritório moderno de São Paulo, com uma linha de montagem taylorista evidenciada em hierarquias claras, rigor em procedimentos de projeto, concatenação na gestão das obras, mobilizando técnicas de vanguarda sempre.

A cadeia produtiva fordista evidencia-se nos carimbos do Escritório, lembrando que os protagonistas jamais assinaram os projetos. Raramente se vê assinatura de Ramos de Azevedo nos desenhos, tampouco de Ricardo Severo ou Arnaldo Dumont Villares. Tratava-se de obras coletivas, nas quais cada parte cabia a um profissional, em geral eternizado com as abreviaturas dos seus nomes nos carimbos.

Por exemplo, nos projetos da nova sede dos Correios e Telégrafos aparecem as iniciais "F.R.", de Felisberto Ranzini, como desenhista, e "A.G.", de Américo Giglio, como copista, que significam que o primeiro foi incumbido do projeto e o segundo do desenho. No projeto do Palácio das Indústrias aparecem "D.R.", de Domiziano Rossi, como desenhista, e "L.Z." (?) como copista. Já nos projetos do Mercado Central aparecem "A.G.", Américo Giglio, como desenhista, e “D.P.”, Domingos Pellicciotta, como copista.

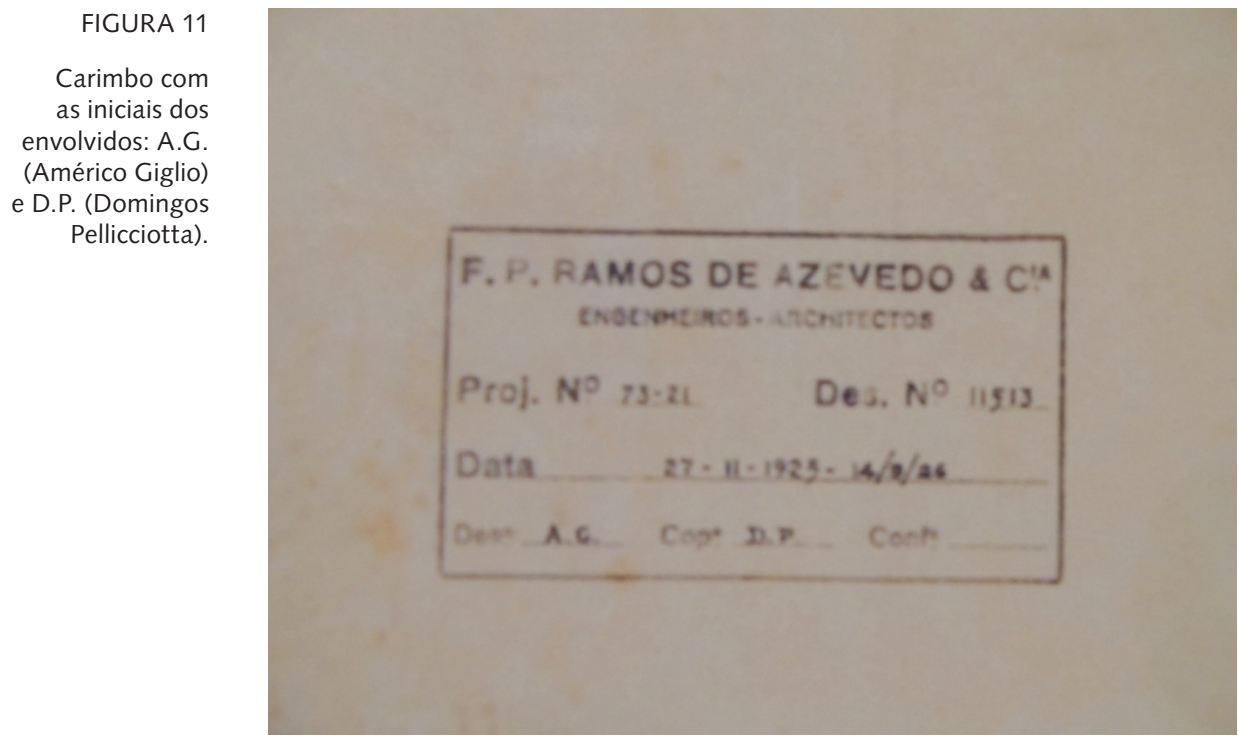


Outra curiosidade revelada pelo Prof. Dr. Nicola Paciléo Netto é que os membros do Escritório eram chamados por suas iniciais: "F.R." (Felisberto Ranzini), "D.R." (Domiziano Rossi), "D.P.” (Domingos Pellicciotta), "A.G.” (Américo Giglio), assim como os demais.

Isso coloca em xeque toda uma linha historiográfica que insiste em creditar a arquitetura do século XIX a determinados demiurgos, desconsiderando-se as cadeias produtivas, as assinaturas múltiplas que faziam dessas edificações verdadeiras obras coletivas. Isso impõe outro tipo de abordagem que privilegia mais os escritórios e menos seus protagonistas.

A foto do $13^{\circ}$ andar do Edifício Britânia supracitada nos dá a medida da cadeia produtiva, mostrando arquitetos, engenheiros e desenhistas engravatados, trabalhando em pranchetas modernas, lembrando-nos dos escritórios contemporâneos, como o de Norman Foster por exemplo.

Os projetos do Mercado Municipal e do Estádio do Pacaembu dão a ver também que o Escritório cuidava do geral aos pormenores, desenhando a caixilharia, as ferragens e em alguns casos até mesmo o mobiliário, depois executados pelo Liceu de Artes e Ofícios com uma notável coerência estética.

FIGURA 12

"Vitrines e Prateleiras para o novo mercado - Secção de ovos", 27/04/1932.

Todo o projeto do mobiliário do Mercado Municipal foi assinado pelo Liceu de Artes e Ofícios. Arquivo Histórico de São Paulo.

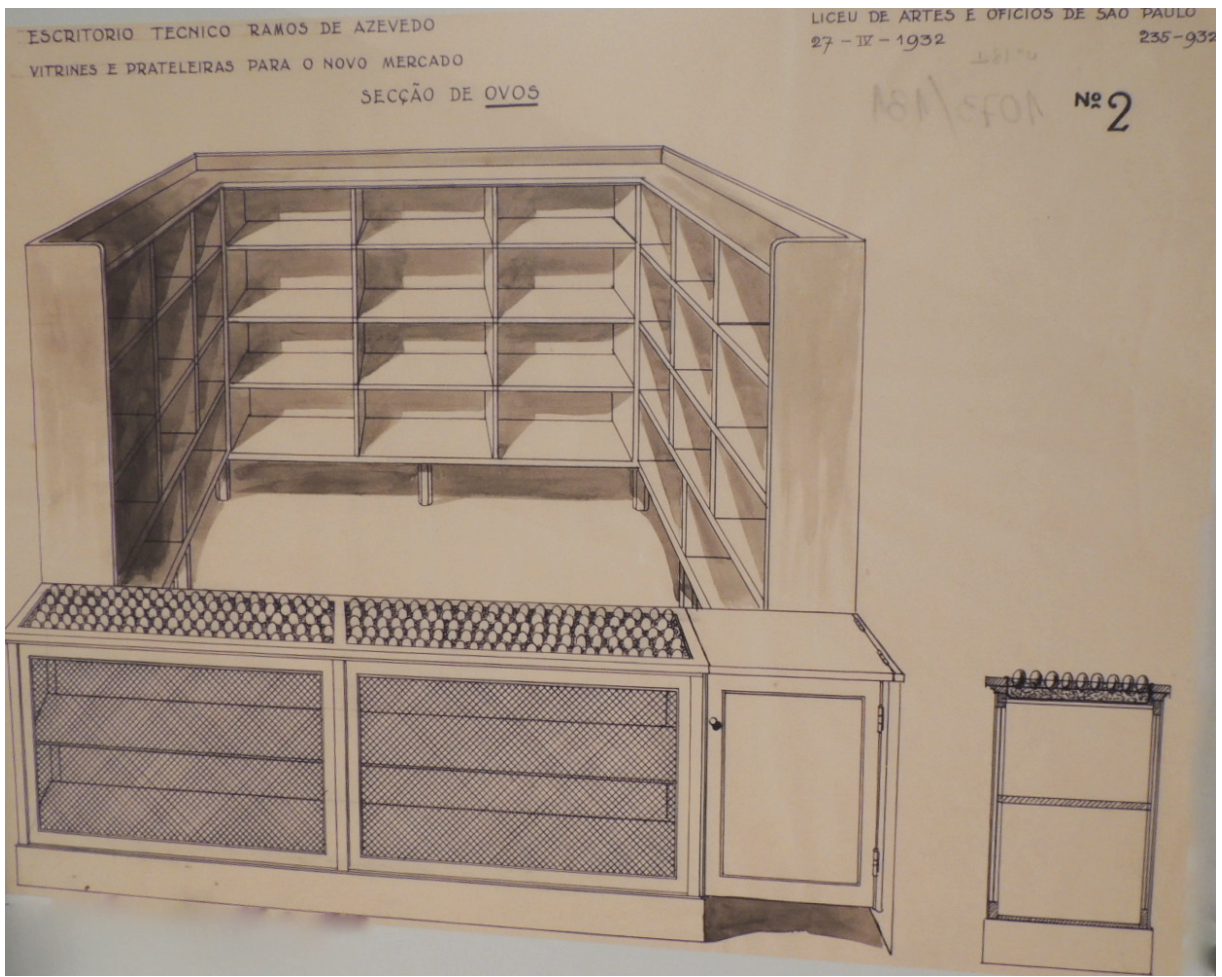


FIGURA 13

Projeto do Conjunto Poliesportivo do Pacaembu. Arquivo

Histórico de São

Paulo.

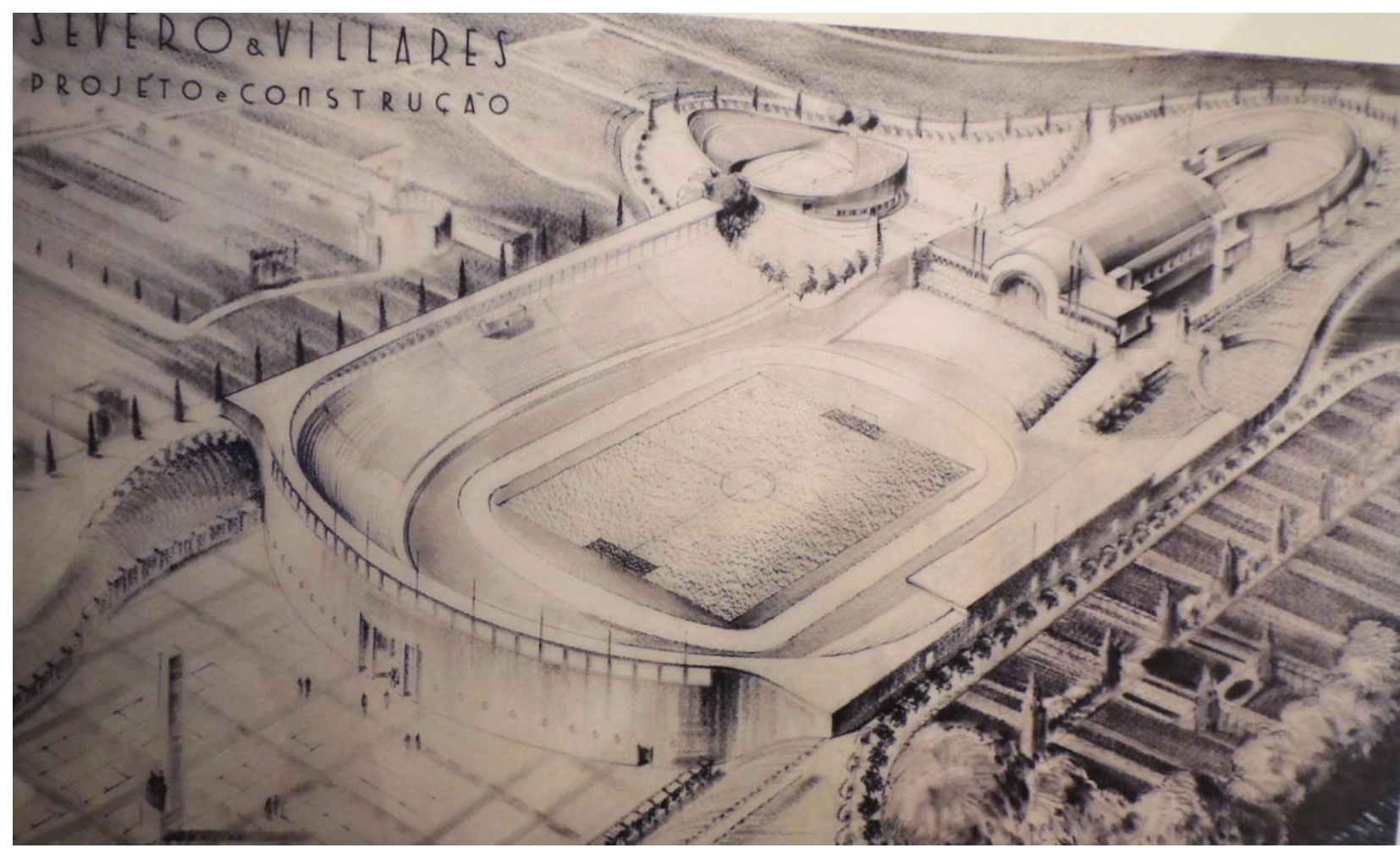

FIGURA 14

Mobiliário da Sala de

Rádio do Conjunto

Poliesportivo do

Pacaembu, todo

ele projetado em

estilo art déco

executado pelo Liceu

de Artes e Ofícios.

Notar detalhamento

dos acabamentos.

Arquivo Histórico de

São Paulo.

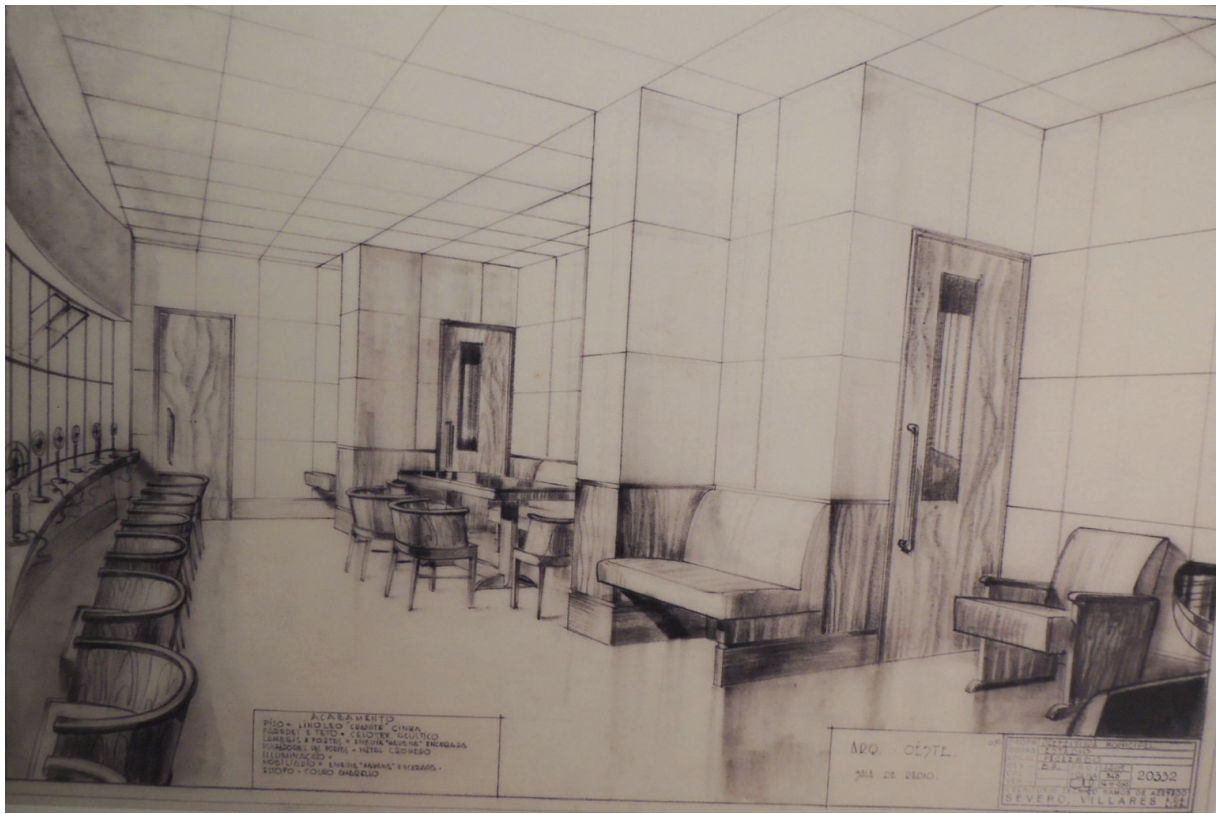


Os carimbos revelam ainda que as obras tinham números e que as folhas de projeto eram seriadas, numa linha de montagem industrial pormenorizadamente organizada e relacionada em amplas listas de obras.

As edificações eram feitas em tempo recorde. O Palácio dos Correios foi construído em apenas dois anos (de 1920 a 1922, entre projeto, fundação e inauguração), quando hoje seu restauro levou mais de quatro; o Teatro Municipal levou cerca de oito anos e, para tanto, foi montado um escritório provisório no canteiro, do qual Ramos coordenava diariamente a equipe in loco. Muitas obras ocorriam ao mesmo tempo, o que explica o grande número de envolvidos no Escritório, do gabinete ao canteiro.

Por ocasião da conclusão, as obras eram minuciosamente registradas em fotografias que hoje integram as coleções da Faculdade de Arquitetura e Urbanismo da Universidade de São Paulo (FAU-USP) e do Conselho de Defesa do Patrimônio Histórico, Arqueológico, Artístico e Turístico (Condephaat), dando mostras da qualidade dos resultados.

Sem sombra de dúvida foi Ramos de Azevedo o mentor dessa cadeia produtiva, e fica no ar a pergunta: onde teria se inspirado? Quiçá no curso preparatório para ingresso na Escola Militar da Praia Vermelha aos 18 anos, quiçá no breve estágio nas obras ferroviárias em Campinas junto do Conde de Parnaíba antes de ir para Gante, quiçá na formação recebida na Bélgica (1875-1878), quiçá nos sete anos de atividade em Campinas (1879-1886), após retornar da Bélgica, assinando as grandes obras da cidade (conclusão da Matriz Nova, Matadouro, Mercado Municipal, Casa de Câmara e Cadeia, Bosque dos Jequitibás, Circolo Italiani Uniti), quiçá junto de Antonio Francisco de Paula Souza, cuja formação politécnica em solos suiço-germânicos (Escolas Politécnicas de Zurique e do Grão-Ducado de Baden, em Karlsruhe, Alemanha) lhe teria treinado a racionalizar projetos e obras em escala industrial. Não podemos nos esquecer de que Paula Souza foi chefe da Inspetoria Geral de Obras Públicas da Província de São Paulo (1868-1869), da Superintendência de Obras Públicas (1890-1891) e da Secretaria da Agricultura, Comércio e Obras Públicas do Estado de São Paulo (1898-?), e que hierarquias semelhantes às das instituições públicas foram introduzidas tanto na Escola Politécnica, que ele fundou, como no escritório do seu mais dileto amigo. 


\section{ARQUITETURA E CIDADE}

O último aspecto que se procurou destacar na exposição é a dimensão urbanística da arquitetura produzida pelo Escritório.

Jamais desenhados isoladamente, os projetos revelam uma nítida preocupação urbanística, em geral, auxiliando na composição de uma paisagem urbana que se queria modernizar.

Para a exposição, elaboramos um mapa com as obras ainda existentes, sugerindo uma promenade pelo Centro Histórico para que o público geral pudesse visitar as obras in situ e apreciar as privilegiadas perspectivas e visualidades que as edificações ensejam. Tanto os principais projetos da primeira fase como os da segunda coroaram ou polarizaram as operações de "Embelezamento e Melhoramentos Urbanos" então em curso, ajudando a modelar e aparatar uma cidade de feições provincianas desfalcada de tudo.

Cabe salientar que o Escritório assinou os projetos dos principais edifícios institucionais exigidos pelo governo republicano em fase de afirmação. Assinou o conjunto do Pátio do Colégio, o conjunto da Luz, o conjunto dos edifícios públicos que ornamentaram o megaprojeto de urbanização das várzeas do Anhangabaú e do Tamanduateí, bem como da Praça da República.

As sensíveis implantações das edificações ancoram a expansão da cidade em todas as direções, dando o tom às operações urbanas encabeçadas pela municipalidade.

Nota-se a esmerada composição do conjunto Pátio do Colégio, do conjunto da Escola Politécnica e do Liceu de Artes e Ofícios na Luz e do conjunto de edificações do Parque do Anhangabaú e do Parque D. Pedro II. No Anhangabaú, o ponto alto é o Theatro Municipal, cuja esplanada articula-se visualmente à Praça do Patriarca, também ela desenhada pelo Escritório que ali assinou os edifícios Lutetia e Barão de Iguape (já demolido). 
FIGURA 15

Projeto da Esplanada do Theatro Municipal. Arquivo

Histórico de São

Paulo.

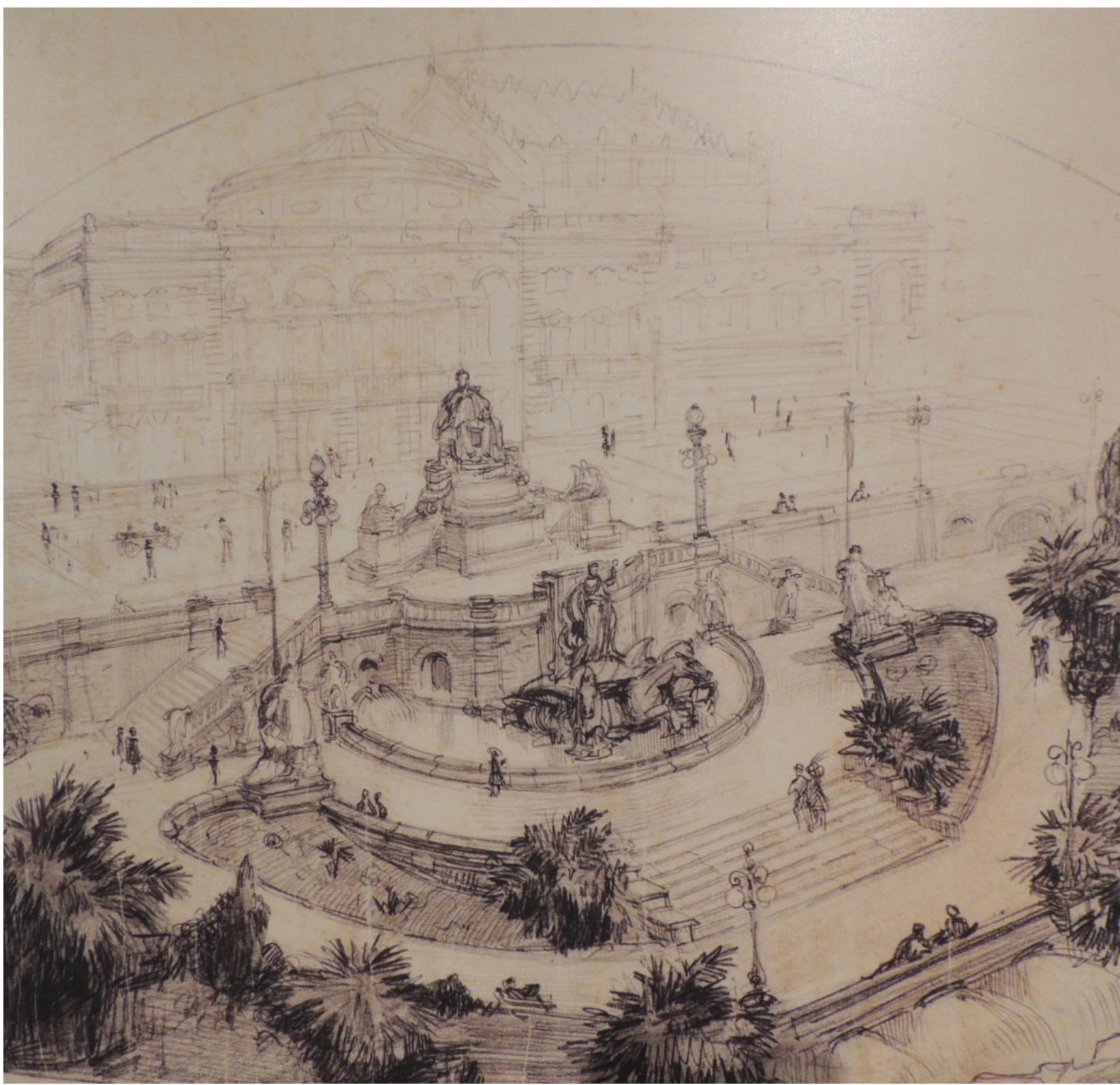

Coroando o Plano Bouvard, o Escritório assinou ainda os dois ícones do Parque D. Pedro II, o Mercado Central e o Palácio das Indústrias.

No centro da cidade, marcou também a paisagem uma série de obras encomendadas por particulares, envolvendo projetos para edifícios de uso misto, bancos, hotéis e outras tantas demandas da Metrópole do Café em expansão. Nos novos bairros, o Escritório assinou um conjunto expressivo de palacetes de rara beleza e coerência estética. 
$\mathrm{Na}$ segunda fase encabeçada por Arnaldo Villares, destacam-se arranha-céus art déco de inspiração nova-iorquina, como o Edifício Azevedo Villares, hoje sito à Rua do Tesouro, n. 23, na esquina com a Rua 15 de Novembro.

FIGURA 16

Perspectiva do Edifício Azevedo Villares,

hoje sito à Rua do

Tesouro, n. 23, na esquina com a Rua 15 de Novembro. Trata-se exatamente

da vista que temos hoje ao descortiná-lo do Pátio do

Colégio. Coleção dos herdeiros de Arnaldo Dumont Villares.

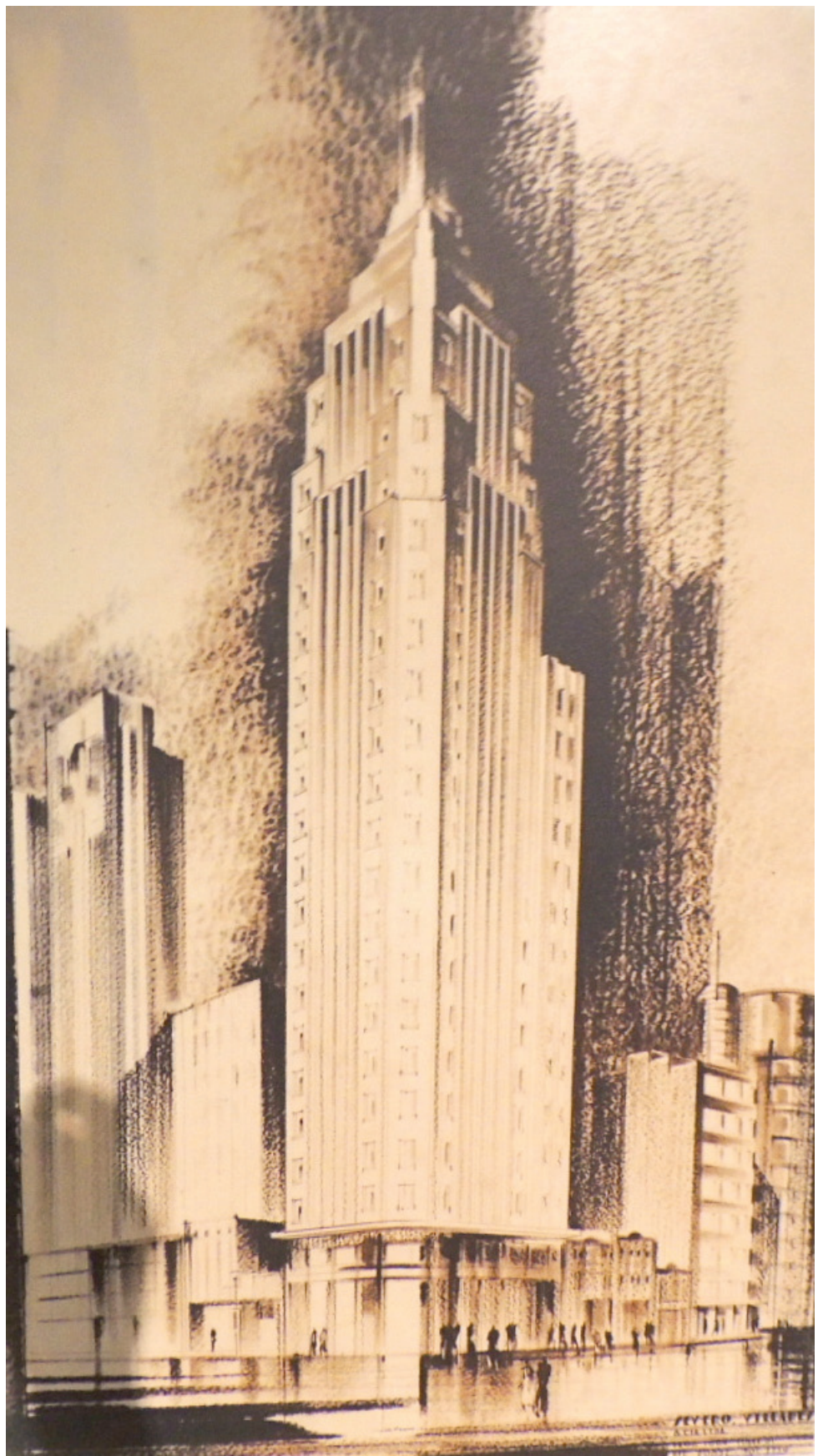


O mesmo perfil possuem a sede da Cia. Paulista de Seguros (atual Liberty Paulista) e o Edifício Britânia na Rua Libero Badaró, o Edifício José Paulino Nogueira no Largo do Paissandu, a sede do Instituto Brasileiro do Café na Rua 15 de Novembro, o Jockey Club na Cidade Jardim, todos eternizados nos diversos cartões comemorativos do Escritório.

FIGURA 17

Ícones do Escritório eternizados no cartão de Natal e Ano-Novo em 1943. Coleção dos Herdeiros de Arnaldo Dumont Villares.

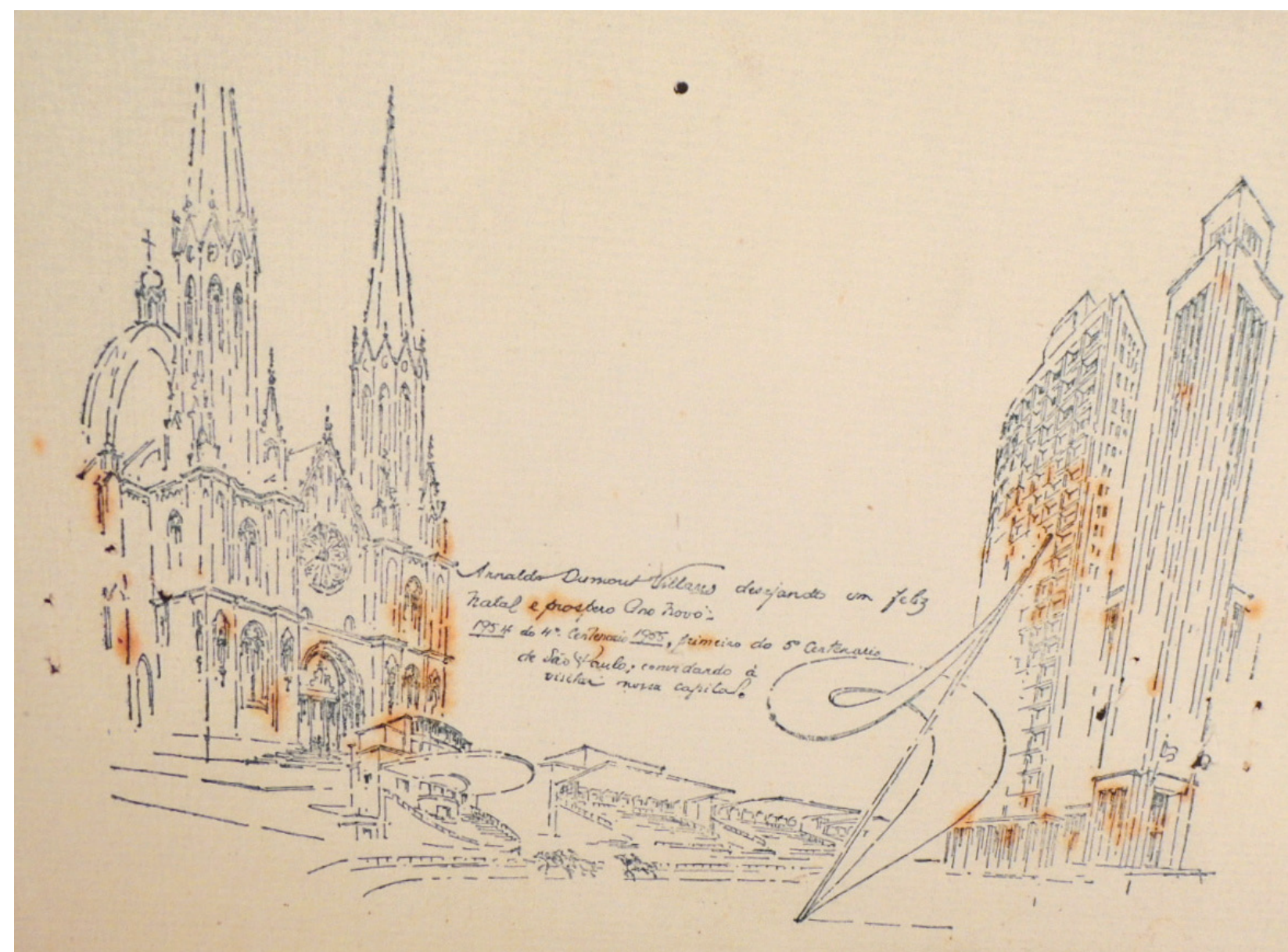

Os edifícios Liberty Paulista e Britânia auxiliam na composição da fachada do Vale do Anhangabaú, assim como o Edifício José Paulino Nogueira situa-se para ser visto de uma das avenidas radiais que emanam do Largo do Paissandu, a Avenida Rio Branco.

Embora atendessem às demandas de um mercado imobiliário rentista 
efervescente, os projetos e as obras esmeravam-se em qualidade.

Os desafios impostos pela verticalização e pelo uso do concreto armado ensejaram inovações muitas vezes só sequenciadas décadas mais tarde. Esse é o caso, por exemplo, da sede da Cia. Paulista de Seguros (atual Liberty Paulista), cujo solo nas encostas do Vale do Anhangabaú cedeu 50 centímetros, implicando o congelamento do terreno por longos dois anos, com tecnologia importada da Bélgica só aplicada nos anos 1980, durante as obras do metrô na região.

Estruturada em quatro módulos - "O Dr. Ramos e seus Parceiros (1886-1928)", “As Obras Públicas (1886-1928)”, "Empresário e Capitalista: as Obras para Particulares (1886-1928)" e "A segunda fase: Escritório F. P. Ramos de Azevedo, Severo \& Villares (1928-1965)" -, a exposição revela a seriedade e magnitude do Escritório, cujo legado deve inspirar as novas gerações de engenheiros e arquitetos pelos valores mobilizados, impressos na arquitetura e na cidade que ajudou a construir.

A sensação ao mergulhar no tema é de ter aberto uma Caixa de Pandora, cheia de surpresas ainda por explicar e linhas de pesquisa a desbravar, ensejando novos voos historiográficos.

\section{REFERÊNCIAS}

CARVAlHO, M. C. W. de. Ramos de Azevedo. São Paulo: Edusp; Fapesp, 2000.

LEMOS, C. Ramos de Azevedo e seu escritório. São Paulo: PINI, 1993.

MELLO, J. Ricardo Severo: da arqueologia portuguesa à arquitetura brasileira. São Paulo: Annablume; Fapesp, 2007.

RECEBIDO EM: 07/05/2015

APROVADO EM: 18/05/2015

\section{BEATRIZ PICCOLOTTO SIQUEIRA BUENO}

Graduação em História pela Universidade de São Paulo (1990), graduação em Artes Plásticas pela Fundação Armando Álvares Penteado (1988) e doutorado em Arquitetura e Urbanismo pela Universidade de São Paulo. Desde 2002, leciona as disciplinas Estudos de Urbanização no Departamento de História da Arquitetura e Estética do Projeto na Faculdade de Arquitetura e Urbanismo da Universidade de São Paulo. E-mail: bpsbueno@gmail.com. 